\title{
Stop, Look, and Listen: Tips for Talking to Older Adults 1
}

\section{Carolyn S. Wilken ${ }^{2}$}

Three simple words can help you talk to the older adults in your life: stop, look, and listen. These words are important when you are in everyday conversation. But they are even more important when you are trying to solve a problem or get essential information. It only takes a little time to stop, look, and listen. When you do, you will quickly find that you will feel less stressed. And, your older friend or family member will feel less frustrated and more understood.

\section{Stop}

Stop what you are doing and focus on your conversation. Of course, we talk to each other while we are doing other things. Talking while we do the dishes or drive the car is normal. Those are good times to talk about the weather, whom we visited with last weekend, or how cute our grandchildren are. But it's different when we want to talk about something important. When we want to ask about a problem or be sure someone understands when their doctor appointment is, we must stop, look, and listen. When we don't stop what we are doing, our older friend or family member may not hear or understand us. We may also miss important nonverbal messages that they are sending. For example, while coming out of the doctor's office you may quickly ask what the doctor said, but you may also be thinking about what you need at the grocery store. Take the time to stop and ask about the doctor's comments before moving on. Focus on the appointment and ask for details while the information is fresh on your older family member's mind.

\section{Look}

Look at the older person when you are talking to them. Looking directly at a person lets them know that we are paying attention and that we care about what they have to say. Because most older adults have some hearing loss, they hear better when they can look at the person who is talking. Without realizing it, most of us increase our hearing by reading lips. It is easier to read lips when the listener can clearly see the speaker's face. So face the person you are talking to, avoid eating or drinking while you are talking, and be sure to speak in a strong, clear voice.

\section{Listen}

Listen with more than your ears. Listen for more than the words. Listen for unspoken messages. What

1. This document is FCS 2225, one of a series of the Department of Family, Youth and Community Sciences, Florida Cooperative Extension Service, Institute of Food and Agricultural Sciences, University of Florida. Publication date: July 2004. Please visit the EDIS Web site at http://edis.ifas.ufl.edu

2. Carolyn S. Wilken, associate professor, Department of Family, Youth and Community Sciences, Cooperative Extension Service, Institute of Food and Agricultural Sciences, University of Florida, Gainesville, FL 32611. Reviewed by Mary Harrison, professor, University of Florida, and Lynn Domenech, M.Ed., owner, Comfort Keepers.

The Institute of Food and Agricultural Sciences (IFAS) is an Equal Employment Opportunity - Affirmative Action Employer authorized to provide research, educational information and other services only to individuals and institutions that function without regard to race, creed, color, religion, age, disability, sex, sexual orientation, marital status, national origin, political opinions or affiliations. For information on obtaining other extension publications, contact your county Cooperative Extension Service office. Florida Cooperative Extension Service / Institute of Food and Agricultural Sciences / University of Florida / Larry R. Arrington, Interim Dean 
is your older relative or friend telling you with his or her body language? Listen for the person's tone of voice-is he or she angry, sad, scared, or excited? Listen for the message you see in the older adult's face or posture. Listen with your ears, your eyes, your mind, and your heart.

\section{Toward Better Communication}

Three simple words can prevent many misunderstandings. When we stop, look, and listen we are showing our older relative or friend that we not only care, but also want to understand and to help. These three simple words are just the start of better communication. The following tips will also help you communicate with older adults in your life:

- Involve older adults in decision making

- Communicate openly and honestly

- Focus on abilities not disabilities

- Listen for feelings of guilt, grief, and sadness

- Involve affected family members in important conversations 